\title{
Production Scheduling of Open Pit Metal Mine with Ecological Cost
}

\author{
Xiaochuan $\mathrm{Xu}^{1}$, Xiaowei $\mathrm{Gu}^{1 *}$, Qing Wang ${ }^{1}$, Qingyu Zhu ${ }^{1}$ and Jianping Liu ${ }^{1,2}$ \\ ${ }^{1}$ College of Resource and Civil Engineering, Northeastern University, Shenyang, China; \\ ${ }^{2}$ Dongmei Foundation Company of Shenyang, Shenyang, China
}

\begin{abstract}
The ecological costs related to the various optimized production schemes were calculated based on the designed ultimate pit. Moreover, the influence of the ecological costs on the selection of production schemes was discussed. In one designed pit, a series of geologically optimum pushbacks with sufficiently small increment were produced using the floating cone method founded on the principle of the highest metal content. Then all the pushbacks were reordered by the dynamic network diagram. The production scheme with the maximum NPV route was considered as the optimum one. The ecological impacts produced by mining were quantified and the ecological cost calculation models, which contain the direct eco-value loss, the indirect eco-value loss, the eco-restoration cost and the carbon emission cost were proposed. In one big open pit mine case, various production schemes were optimized and the one with maximum NPV was selected without taking into account the eco-costs. The scheme with the maximum comprehensive profit was obtained by calculating the eco-cost of each scheme. The results showed that the best scheme considered with the eco-cost was not the scheme with the maximum NPV. Therefore, the eco-cost presents the effect on the selection of the best production scheme.
\end{abstract}

Keywords: open pit mine, production scheme, optimization, ecological cost

\section{Introduction}

Optimizing production scheme is to determine the mining quantities of ore and rock, the pushing position of stope each year, and maximize the NPV of mine. In the theory, production scheming optimization has gone through trial and error (Pana and Carlson 1966), linear programming method (Johnson 1968), mixed integer programming (Gershon 1983), integer mapping (Kim and Cai 1990), dynamic programming et al ( $\mathrm{Gu}$ et al 2014). In recent years, the study on production scheduling optimization has been focused on two aspects. On the one hand, the study is to solve the investment risk caused by the uncertainties of economic and geological environment (Ramazan and Dimitrakopoulos 2013, Marcotte and Caron 2010, Lamghari and Dimitrakopoulos 2012, Godoy and Dimitrakopoulos 2004, Benndorf and Shishvan 2014). On the other hand, the emphasis of the study was on reducing the problems for the optimization algorithm, to make it more efficient and practical (Cullenbine et al 2011, Shishvan and Sattarvand 2015, Askari-Nasab et al 2011, Nasab et al 2010). However, different production schemes cause different damage of mine land and pollutant emission, thus triggering environment problem. With the improvement of people's consciousness of environment protection, the environmental issue of mining has been attracting more and more attention.

Based on the theory of ecological footprint, $\mathrm{Xu}$ et al (2014) built ecological footprint model and ecological cost model of mine, and employed an iterative algorithm to optimize ultimate pit considering ecological cost, by which maximum economic benefits and ecological benefits can be obtained. Badiozamani and Askari-Nasab (2014) optimized production scheme of open pit oil sand mine considering tailings pond reclamation. By studying the relation between mine transportation equipment performance and energy consumption, Peralta et al (2016) found that a reasonable maintenance schedule can improve the use of energy and reduce greenhouse gas emission by studying the relation between mine transportation equipment performance and energy consumption. Gholamnejad (2009) put ecological restoration cost into cutoff calculation and optimized the best cutoff via lane method. So far, researches on mine sustainable development are primarily still in qualitative analysis phase. The environment disruption, society issues and economic benefit caused by the mineral resources have not been quantified in the form of money.

In this article, ecological cost caused by mining activity is divided into direct eco-value loss, indirect eco-value, ecorestoration cost and carbon emission cost. Firstly, multiproduction schemes are optimized via metal-miner software. Then ecological cost caused by different schemes is figured out. At last, influence of eco-costs on how to choose the production scheme is discussed.

\section{The Model of Production Scheme Optimization}

In a designed pit, if the excavation quantities are fixed in a given year, there are many sections which have the same excavation quantities and meet the requirement of working slope angle. The best choice of determining the optimum

* Corresponding Author: X.W. Gu, 493212755@qq.com, phone: +86 024-83679009

Copyright (C) 2017 Canamaple Academia Services, http://press.camdemia.ca

DOI: 10.15273 /gree.2017.02.011 
mining position in this year is to find out a section that contains the maximum metal content form all sections. The section is named geologically optimum working-slope pushback and showed by $P$. Cone elimination method is used to remove some blocks which meet the given increments (such as $\Delta P$ ) and the average grade are minimum. Then, a series of nest pushbacks $\left(\left\{P^{*}\right\}_{N}\right)$ which differ by $\Delta P$ are generated(Gu et al 2014).

After obtaining geologically optimum working-slope pushbacks $\left(\left\{P^{*}\right\}_{N}\right)$, the production scheme optimization is to find out the optimum subsequence $\left(\left\{P^{*}\right\}_{M}\right)$ from the $\left\{P^{*}\right\}_{N}$ (Gu et al 2011).

\section{Ecological Cost Calculation}

The environment problem caused by mining is transformed into the eco-cost which is considered in mine project evaluation and design optimization. It is the evaluation basis of achieving economy and ecology integral optimization. The eco-costs of resource exploitation contain four parts, direct eco-value loss, indirect eco-value loss, eco-restoration cost and the carbon emission cost.

\subsection{Direct eco-value loss}

Land acquisition cost is the fee of land usage right, which is needed to be paid for the landowners by the mine enterprise. It reflects the direct value loss of damaged land. So, Land acquisition price can show the direct eco-value loss. If mine requisitions land in phasing, the direct eco-value loss, $C_{Z, t}$, at time $t$ is,

$$
C_{Z, t}=A_{z, t} \cdot \frac{c_{z}(1+u)^{t}}{(1+d)^{t}}
$$

where, $A_{z, t}$ is the area of land acquisition at time $\mathrm{t}, \mathrm{hm}^{2} ; c_{z}$ is the price of land acquisition at present, US\$/ $/ \mathrm{hm}^{2}$.

\subsection{Eco-restoration cost}

Eco-restoration cost is used to pay for recovering ecological function of damaged land by mining activity and conserving vegetation after reclamation project. The eco-restoration cost present worth, $C_{r, t}$, in US $\$$, at time $t$ is,

$$
C_{r, t}=A_{r, t} \cdot \frac{c_{r}(1+u)^{t}}{(1+d)^{t}}
$$

where, $A_{r, t}$ is the area of restoration at time $\mathrm{t}, \mathrm{hm}^{2} ; c_{r}$ is the eco-restoration cost of forest, US $\$ / \mathrm{hm}^{2}$.

\subsection{Indirect eco-value loss}

Indirect eco-value loss is ecological service value loss of damaged land except direct eco-value. The land damaged by mining is primarily woodland. So, all damaged land can be equally regarded as the woodland. According to human understanding of forest ecological service function, the indirect eco-value is mainly reflected in the water conservation, wind prevention and sand stabilization, purifying environment, climate regulation, photosynthetic carbon fixation, releasing oxygen, soil conservation, nutrient cycling and maintaining bio-diversity et al.
(1) Purifying air value

Forest has the function of absorbing pollutant in the air and, such as $\mathrm{CO}_{2}, \mathrm{SO}_{2}$ and $\mathrm{NO}_{\mathrm{x}}$, detaining dust and secreting bactericidin. The value of air purification, $V_{a}$, in US $\$ / \mathrm{a} / \mathrm{hm}^{2}$, is calculated as:

$$
V_{a}=q_{f} \lambda_{c} c_{c}+y_{s} c_{s}+y_{n} c_{n}+y_{d} c_{d}+y_{g} c_{g}
$$

where, $q_{f}$ is the net primary production (NPP) of woodland, $\mathrm{t} / \mathrm{hm}^{2} / \mathrm{a} ; \lambda c$ is the fixed parameter of $\mathrm{CO}_{2} ; c_{c}$ is the treatment cost of $\mathrm{CO}_{2}$, US\$/t; $y_{s}$ is the absorbing ability of $\mathrm{SO}_{2}$, $\mathrm{t} / \mathrm{hm}^{2} / \mathrm{a} ; c_{s}$ is the treatment cost of $\mathrm{SO}_{2}$, US $\$ / \mathrm{t} ; y_{n}$ is the absorbing ability of $N O_{X}, \mathrm{t} / \mathrm{hm}^{2} / \mathrm{a} ; c_{n}$ is the treatment cost of $N O_{X}, \mathrm{US} \$ / \mathrm{t} ; y_{g}$ is the bactericidin secretory capacity of forest, $\mathrm{t} / \mathrm{hm}^{2} / \mathrm{a} ; c_{g}$ is the price of bactericidin, US\$/t.

(2) Releasing oxygen value

Calculating oxygen releasing value of forest, $V_{o}$, in $\mathrm{US} \$ / \mathrm{a} / \mathrm{hm}^{2}$, is similar to carbon fixation value estimation:

$$
V_{o}=q_{f} y_{o} c_{o}
$$

where, $y_{o}$ is the parameter of oxygen releasing; $c_{o}$ is the production cost, US\$/t.

\section{(3) Conserving water value}

The water conservation value of woodland, $V_{h}$, in US $\$ / \mathrm{a} / \mathrm{hm}^{2}$, is calculated as:

$$
V_{h}=10 j k r_{h} c_{h}
$$

where, $j$ is the average rainfall of years, mm/a; $k$ is the ratio of runoff generation in the total rainfall; $r_{h}$ is the runoff coefficient of woodland compared with bare land; $c_{h}$ is the price of headwaters, US $\$ / \mathrm{m}^{3}$.

(4) Conserving soil value

The soil conservation capacity of forest eco-system mainly reflects on the resisting wind and water erosion. The conserving soil value of woodland, $V_{w}$, in US $\$ / \mathrm{hm}^{2} / \mathrm{a}$, is calculated as:

$$
V_{w}=\frac{y_{p}}{10000 \rho h} v
$$

Where, $y_{p}$ is the soil conservation capacity of woodland, $\mathrm{t} / \mathrm{hm}^{2} / \mathrm{a} ; \rho$ is the volume weight of soil, $\mathrm{t} / \mathrm{m}^{3} ; h$ is the thickness of soil, $\mathrm{m} ; v$ is the annual profit of some cropland transformed from conserving soil, US $\$ / \mathrm{hm}^{2}$.

(5) Nutrient cycling value

Nutrient cycling mechanism of woodland forms soil nutrient, containing nitrogen $(\mathrm{N})$, phosphorus $(\mathrm{P})$ and potassium $(\mathrm{K})$. The nutrient cycling value of woodland, $V_{\mathrm{n}}$, in US\$/hm²/a, is calculated as:

$$
V_{n}=q_{f}\left(k_{N} p_{N}+f_{P} k_{P} p_{P}+k_{K} p_{K}\right)
$$

where, $k_{\mathrm{N}}, k_{\mathrm{P}}$ and $k_{\mathrm{K}}$ are the ratio of $\mathrm{N}, \mathrm{P}$ and $\mathrm{K}$ in the $q_{f}$, respectively; $p_{\mathrm{N}}, p_{\mathrm{P}}$ and $p_{\mathrm{K}}$ are the prices of $\mathrm{N}, \mathrm{P}$ and $\mathrm{K}$, respectively; $f_{\mathrm{P}}$ is the conversion coefficient form $\mathrm{P}$ to $\mathrm{P}_{2} \mathrm{O}_{5}$.

(6) Total indirect eco-cost estimate.

As model mentioned above, the total indirect eco-cost of woodland damaged by mining, $f_{E E}$, in US\$, is calculated as:

$$
f_{E E}=V_{a}+V_{o}+V_{h}+V_{w}+V_{n}
$$

The destruction region of mine mainly occurs at stope, refuse dump and tailings pond. According to the state transition in fig.1, the area of $S_{i, j}$ at time $I, A_{p}(i, j)$, can be measured by the software on the drawing. This area is the damaged area at time $i$. 
The damaged area of refuse dump, $A_{w}(i, j)$, corresponds to the accumulated volume of stripping rock, $V_{w}(i, j)$, at time $i$.

$$
A_{w}(i, j)=\left\{\begin{array}{lr}
A_{w 0} & V_{w}(i, j)<V_{w 0} \\
\frac{V_{w}(i, j) r_{w}}{\frac{H_{w}-V_{w 0}}{V_{w}}\left[V_{w}(i, j)-V_{w 0}\right]+H_{w 0}} S_{w} & V_{w}(i, j) \geq V_{w 0}
\end{array}\right.
$$

where, $A_{w 0}$ is the leveled area of refuse dump at an early stage, $\mathrm{hm}^{2} ; S_{w}$ is the form factor of refuse dump; $r_{w}$ is the expansion factor of cupped rock; $H_{w}$ is the height of refuse dump, m; $H_{w 0}$ is the initial height of refuse dump, m; $V_{w 0}$ is the initial volume of refuse dump, $\mathrm{m}^{3}$.

Tailings pond is built one-time for the fluid character of tailings. So, the damaged land of tailings pond occurs at the beginning of mining other than year by year. That is the accumulating damaged area of tailings pond every year is equal to the total damaged area of tailings pond, $A_{t}$, in $\mathrm{hm}^{2}$.

$$
A_{t}=\frac{Q_{t}}{\rho_{t} \cdot H_{t}} \cdot S_{t}
$$

where, $Q_{t}$ is the tons of tailings, $10^{4} \mathrm{t}$; $S_{t}$ is the form factor of tailings pond; $\rho_{t}$ is the proportion of tailings, $\mathrm{t} / \mathrm{m}^{3} ; H_{t}$ is the depth of tailings pond, $\mathrm{m}$.

\subsection{The carbon emission cost of energy consumption}

The impact of energy consumption on the environment mainly reflects in greenhouse gas emission causing global warming. The energy consumption of open pit mining mainly results from stope and dressing plant. Stope mainly consumes diesel, petrol and power (coal) and the carbon emission cost of energy consumption can come down to mining-stripping per unit ton. Dressing plant mainly consumes power and the carbon emission cost of energy consumption can come down to ore dressing per unit ton. So, the carbon emission cost of stope consuming energy, $c_{e o}$, in $\mathrm{US} \$ / \mathrm{t}$, is calculated as:

$$
c_{e o}=\left(e_{d} f_{d}+e_{g} f_{g}+e_{e o} b a_{c} f_{c}\right) c_{c}
$$

The carbon emission cost of dressing plant consuming energy, $c_{d o}$, in US $\$ / \mathrm{t}$, is calculated as:

$$
c_{e d}=e_{e d} b a_{c} f_{c} c_{c}
$$

where, $e_{\mathrm{d}}$ and $e_{\mathrm{g}}$ are the diesel and petrol consumptions per ton of mined ore or stripped rock, respectively, $\mathrm{t} / \mathrm{t} ; e_{e o}$ and $e_{e d}$ are the power consumptions per ton of dressed ore, $\mathrm{kwh} / \mathrm{t}$; $f_{\mathrm{d}}, f_{\mathrm{g}}$ and $f_{\mathrm{c}}$ are the carbon emission factor of diesel, petrol and coal, respectively; $b$ is the ratio of using coal in the generating capacity; $a_{\mathrm{c}}$ is the coal consumption to generate a unit of electricity, $\mathrm{t} / \mathrm{kwh}$.

The carbon emission cost of energy consumption from $S_{i-1, k}$ at time $i-1$ to $S_{i, j}$ at time $i$ is calculated as:

$$
C_{C}(i, j)=\left(O_{i, j}(i-1, k)+W_{i, j}(i-1, k)\right) \cdot c_{e o}+O_{i, j}(i-1, k) \cdot c_{e d}
$$

\section{Case Study}

The algorithm and model built above are applied in a large open pit metal mine, which locates in the north of china. The mine has been mined over years and the remaining reserves are about 0.4 billion tons. The ecological system damaged by mining is mainly deciduous broad-leaved forest. Based on the mining status of stope and related technical and economic parameters of mine, an ultimate pit was optimized with 377.24 million tons of ore and 1061.70 million ton of rock. In the pit, about 315 pushbacks were generated while the increment was 0.25 million tons and the working slope angle was $20^{\circ}$. The technical and economic parameters used to optimize production scheme are set in

\begin{tabular}{|c|c|c|c|c|c|c|}
\hline $\begin{array}{l}\text { Item } \\
\text { value }\end{array}$ & $\begin{array}{c}\text { Mining } \operatorname{cost}(\mathbf{U S} \$ \mathbf{t}) \\
2.908\end{array}$ & $\begin{array}{c}\text { Stripping } \\
\text { cost(US\$/t) } \\
1.7448 \\
\end{array}$ & $\begin{array}{c}\text { Dressing } \\
\text { cost(US\$/t) } \\
18.902 \\
\end{array}$ & $\begin{array}{c}\text { Concentrate } \\
\text { price(US\$/t) } \\
82.151 \\
\end{array}$ & $\begin{array}{c}\text { Waste in-ore } \\
\text { ratio }(\%) \\
3.5 \\
\end{array}$ & $\begin{array}{c}\text { Waste grade } \\
(\%) \\
10 \\
\end{array}$ \\
\hline Item & $\begin{array}{l}\text { Mining recovery } \\
\text { ratio }(\%)\end{array}$ & $\begin{array}{l}\text { Dressing recovery } \\
\text { ratio }(\%)\end{array}$ & $\begin{array}{c}\text { Cutoff grade } \\
(\%)\end{array}$ & $\begin{array}{c}\text { Concentrate grade } \\
(\%)\end{array}$ & $\begin{array}{c}\text { Rate of cost rise } \\
(\%)\end{array}$ & $\begin{array}{l}\text { Rate of price } \\
\text { rise }(\%)\end{array}$ \\
\hline value & 95 & 82 & 25 & 66 & 2 & 4 \\
\hline
\end{tabular}
Table 1. The parameters of calculating ecological costs are set in Table 2. All monetary values are converted to US

\begin{tabular}{|c|c|c|c|c|c|c|c|}
\hline Parameter & Value & Parameter & Value & Parameter & Value & Parameter & Value \\
\hline$c_{z} /\left(\mathrm{US} \$ / \mathrm{hm}^{2}\right)$ & 348960 & $c_{\mathrm{r}} /\left(\mathrm{US} \$ / \mathrm{hm}^{2}\right)$ & 58160 & $q_{f} /\left(\mathrm{t} / \mathrm{hm}^{2} / \mathrm{a}\right)$ & 6.56 & $\overline{\lambda c}$ & 1.62 \\
\hline$c_{\mathrm{C}} /(\mathrm{US} \$ / \mathrm{t})$ & 50.59 & $y_{\mathrm{S}} /\left(\mathrm{t} / \mathrm{hm}^{2} / \mathrm{a}\right)$ & 0.1521 & $c_{\mathrm{S}} /(\mathrm{US} \$ / \mathrm{t})$ & 162.2921 & $y_{n} /\left(\mathrm{t} / \mathrm{hm}^{2} / \mathrm{a}\right)$ & 0.38 \\
\hline$c_{n} /(\mathrm{US} \$ / \mathrm{t})$ & 2326.4 & $y_{d} /\left(\mathrm{t} / \mathrm{hm}^{2} / \mathrm{a}\right)$ & 21.655 & $c_{d} /(\mathrm{US} \$ / \mathrm{t})$ & 45.9828 & $y_{\mathrm{g}} /\left(\mathrm{t} / \mathrm{hm}^{2} / \mathrm{a}\right)$ & 10.95 \\
\hline$c_{g} /(\mathrm{US} \$ / \mathrm{t})$ & 21.81 & $y_{o}$ & 1.2 & $c_{\mathrm{O}} /(\mathrm{US} \$ / \mathrm{t})$ & 101.9836 & $j /(\mathrm{mm} / \mathrm{a})$ & 800 \\
\hline$k$ & 0.4 & $r_{h}$ & 0.26 & $c_{\mathrm{h}} /(\mathrm{US} \$ / \mathrm{t})$ & 0.1818 & $y_{\mathrm{p}} /\left(\mathrm{t} / \mathrm{a} / \mathrm{hm}^{2}\right)$ & 60.2915 \\
\hline$\rho /\left(\mathrm{t} / \mathrm{m}^{3}\right)$ & 1.3 & $h / \mathrm{m}$ & 0.5 & $v /\left(\mathrm{US} \$ / \mathrm{hm}^{2}\right)$ & 3294.118 & $k_{\mathrm{N}}$ & $4.3 \times 10^{-3}$ \\
\hline$k_{\mathrm{P}}$ & $3.9 \times 10^{-4}$ & $k_{\mathrm{K}}$ & $2.16 \times 10^{-3}$ & $p_{\mathrm{N}} /(\mathrm{US} \$ / \mathrm{t})$ & 319.88 & $p_{\mathrm{P}} /(\mathrm{US} \$ / \mathrm{t})$ & 94.51 \\
\hline$p_{\mathrm{K}} /(\mathrm{US} \$ \mathrm{t})$ & 328.4586 & $f_{\mathrm{P}}$ & 2.2903 & $S_{w}$ & 1.5 & $r_{w}$ & 1.25 \\
\hline$H_{w} / \mathrm{m}$ & 150 & $H_{w 0} / \mathrm{m}$ & 40 & $V_{w 0} /\left(\mathrm{m}^{3}\right)$ & $200 \times 10^{4}$ & $S_{t}$ & 1.5 \\
\hline$\rho_{t} /\left(\mathrm{t} / \mathrm{m}^{3}\right)$ & 1.75 & $H_{t} / \mathrm{m}$ & 100 & $e_{\mathrm{d}} /(\mathrm{t} / \mathrm{t})$ & $5.664 \times 10^{-4}$ & $e_{\mathrm{g}} /(\mathrm{t} / \mathrm{t})$ & $4.1 \times 10^{-6}$ \\
\hline$e_{e o} /(\mathrm{kWh} / \mathrm{t})$ & 1.2 & $e_{e d} /(\mathrm{kWh} / \mathrm{t})$ & 28.5 & $f_{\mathrm{d}}$ & 3.1865 & $f_{\mathrm{g}}$ & 3.1309 \\
\hline$f_{\mathrm{c}}$ & 2.7335 & $b$ & 0.8 & $a_{\mathrm{c}} /(\mathrm{t} / \mathrm{kWh})$ & $4.04 \times 10^{-4}$ & & \\
\hline
\end{tabular}
dollars using an exchange rate of 0.1454 dollar to 1 RMB.

Table 1. The parameters of optimizing mining plan.

Table 2. Parameter values for calculation of ecological costs. 
Based on the parameters set above, capital construction and closing period are set as one year and two years, separately. The land acquisitions of stope and tailings pond are finished in the initial stage of mining, while refuse dump are two phases. The first phase occurs in the initial stage of mining and the volume is 0.25 billion $\mathrm{m}^{3}$. The second phase occurs in the previous year that the first refuse dump finished dumping. Reclamation occurs in three years after mine closed and the reclamation areas of each year are equal. The indirect eco-cost will last for five years after mine closed. The results of production scheme optimization and the eco-costs of each production scheme are listed in Table 3.

Table 3. Production scheduling and ecological costs of schemes.

\begin{tabular}{|c|c|c|c|c|c|c|c|c|c|c|c|c|}
\hline \multirow[b]{2}{*}{ year } & \multicolumn{4}{|c|}{ Scheme I } & \multicolumn{4}{|c|}{ Scheme II } & \multicolumn{4}{|c|}{ Scheme III } \\
\hline & $\begin{array}{c}\text { ore } \\
/ 10^{4} t\end{array}$ & $\begin{array}{l}\text { Waste } \\
/ 10^{4} \mathrm{~m}^{3}\end{array}$ & $\begin{array}{l}\text { NPV/10 } \\
\text { US\$ }\end{array}$ & $\begin{array}{l}\text { Eco-cost } \\
/ 10^{6} \mathrm{US} \$\end{array}$ & $\begin{array}{c}\text { ore } \\
/ 10^{4} t\end{array}$ & $\begin{array}{l}\text { Waste } \\
/ 10^{4} \mathrm{~m}^{3}\end{array}$ & NPV/10 $6 S \$$ & $\begin{array}{c}\text { Eco- } \\
\text { cost } \\
/ 10^{6} \mathrm{US} \$\end{array}$ & $\begin{array}{c}\text { ore } \\
/ 10^{4} t\end{array}$ & $\begin{array}{l}\text { Waste } \\
/ 10^{4} \mathrm{~m}^{3}\end{array}$ & $\begin{array}{l}\text { NPV/10 } \\
\text { US\$ }\end{array}$ & $\begin{array}{l}\text { Eco-cost } \\
/ 10^{6} \mathrm{US} \$\end{array}$ \\
\hline 1 & 7.47 & 20.41 & 0.44 & 339.28 & 7.47 & 20.41 & 0.44 & 339.28 & 7.47 & 20.41 & 0.44 & 339.28 \\
\hline 2 & 1306.63 & 428.42 & 118.53 & 18.78 & 1306.63 & 428.42 & 118.53 & 18.78 & 1306.63 & 428.42 & 118.53 & 18.78 \\
\hline 3 & 1410.41 & 4410.14 & 68.67 & 24.23 & 1291.46 & 4007.06 & 63.12 & 22.23 & 1291.46 & 4007.06 & 63.12 & 22.23 \\
\hline 4 & 1302.08 & 4607.97 & 58.42 & 22.42 & 1302.19 & 4591.76 & 59.37 & 22.38 & 1302.19 & 4591.76 & 59.37 & 22.38 \\
\hline 5 & 1305.03 & 4572.24 & 62.92 & 21.51 & 1305.5 & 4539.3 & 62.77 & 21.46 & 1305.5 & 4539.3 & 62.77 & 21.46 \\
\hline$\ldots$ & $\ldots$ & $\ldots$ & $\ldots$ & $\ldots$ & $\ldots$ & $\ldots$ & $\ldots$ & $\ldots$ & $\ldots$ & . & $\ldots$ & $\ldots$ \\
\hline 22 & 1662.6 & 3026.98 & 128.17 & 11.24 & 1663.23 & 3131.21 & 127.58 & 11.29 & 1664.24 & 3264.59 & 126.74 & 11.37 \\
\hline 23 & 1661.66 & 2605.85 & 130.7 & 10.51 & 1661.23 & 2633.11 & 130.32 & 10.52 & 1660.43 & 2649.25 & 130.27 & 10.52 \\
\hline 24 & 1663.4 & 1817.11 & 133.82 & 9.66 & 1663.01 & 1887.39 & 133.33 & 9.69 & 1663.47 & 1945.8 & 133.05 & 9.72 \\
\hline 25 & 1661.74 & 1271.25 & 137.23 & 8.97 & 1662.38 & 1270.97 & 137.39 & 8.97 & 1662.25 & 1283.55 & 136.88 & 8.97 \\
\hline 26 & 1660.26 & 1625.04 & 134.87 & 8.69 & 1660.42 & 1546.34 & 134.93 & 8.66 & 1660.56 & 1496.83 & 135.27 & 8.64 \\
\hline 27 & & & & & 118.23 & 182.75 & 9.32 & 1.7 & 118.48 & 141.02 & 9.39 & 1.68 \\
\hline \multicolumn{5}{|l|}{28} & & & & & 118.23 & 182.75 & 9.2 & 1.62 \\
\hline \multirow[b]{2}{*}{ total } & \multirow[b]{2}{*}{37137.35} & \multirow[b]{2}{*}{106756.2} & 2450.76 & 916.31 & \multirow[b]{2}{*}{37137.35} & \multirow[b]{2}{*}{106756.2} & 2453.25 & 914.94 & \multirow[b]{2}{*}{37137.35} & \multirow[b]{2}{*}{106756.2} & 2453.10 & 914.48 \\
\hline & & & $\begin{array}{l}\text { Compr } \\
\text { profit: }\end{array}$ & $\begin{array}{l}\text { hensive } \\
1534.45\end{array}$ & & & $\begin{array}{r}\text { Comprehensi } \\
1538 .\end{array}$ & profit: & & & \multicolumn{2}{|c|}{$\begin{array}{l}\text { Comprehensive } \\
\text { profit: } \mathbf{1 5 3 8 . 6 2}\end{array}$} \\
\hline
\end{tabular}

Note: the indirect eco-costs in five years after mine closed are not listed in table 3 while considered in total.

In Table 3, there are top three NPV of production schemes, Scheme I, Scheme II and Scheme III. It can be seen, ore-rock tons of different schemes of each year are diverse and the eco-cost in each year are different as well. Without eco-costs, the maximum NPV of three schemes is Scheme II, whose mining life is 27 years and the NPV is $2453.25 \times 10^{6}$ US\$. With eco-cost, the maximum NPV is Scheme III, whose mining life is 28 years and the comprehensive profit is $1538.62 \times 10^{6}$ US\$. The comprehensive profit of Scheme III is more than Scheme II, is $0.31 \times 10^{6} \mathrm{US} \$$. Different production schemes has different eco-costs which has an impact on choosing scheme.

\section{Conclusions}

Combining production character of mine, the model of calculating eco-cost is built to quantify environment issues caused by resource mining. Top three NPV of production schemes are optimized in the ultimate pit and the eco-costs of different scheme are calculated. It is shown that different scheme leads to different ecological costs. Without ecocosts, the optimum production scheme is Scheme II whose NPV is maximum. With eco-costs, the optimum production scheme is Scheme III which comprehensive is maximum. It is ecological costs that has an impact on choosing production scheme, if environmental issues would be taken into account.

\section{Acknowledgement}

The authors would like to acknowledge the National Natural Science Foundation of China (51474049, 51674062);
National Science Foundation for Young Scientists of China Project (51604061); Liaoning Nature Science Founds (2014020040); Specialized Research Fund for the Doctoral Program of Higher Education of China (20130042110012).

\section{References}

Askari-Nasab, H., Y. Pourrahimian, E. Ben-Awuah and S. Kalantari, 2011. Mixed integer linear programming formulations for open pit production scheduling. Journal of Mining Science, 47(3): 338 - 359.

Badiozamani, M.M. and H. Askari-Nasab, 2014. Integration of reclamation and tailings management in oil sands surface mine planning. Environmental Modelling \& Software, 51(1): 45 - 58.

Benndorf, J. and M.S. Shishvan, 2014. Performance optimization of complex continuous mining system using stochastic simulation. Proceedings of the 4th International Conference on Engineering Optimization, Lisbon, 272 - 278.

Cullenbine, C., R. K. Wood and A. Newman, 2011. A sliding time window heuristic for open pit mine block sequencing. Optimization Letters, 5(3): 365 - 377.

Gershon, M.E, 1983. Mine scheduling optimization with mixed integer programming. Mining Engineering, 35(4): 351 - 354.

Godoy, M. and R. Dimitrakopoulos, 2004. Managing risk and waste mining in long-term production scheduling of open-pit mines. Advanced Mining Consultants Amc Reference Library, 9(9): 19.

Gholamnejad, J, 2009. Incorporation of rehabilitation cost 
into the optimum cut-off grade determination. Journal of the South African Institute of Mining \& Metallurgy, 109(2): 89 - 94.

Gu, X.W., X.C. Xu, Q. Wang and J.P. Liu, 2014. Improving the optimization algorithm of production scheduling for open pit metal mine. Journal of Northeastern University (Nature Science), 35(10): 1492 - 1496.

Gu, X.W., Q. Wang, Y.Y. Zheng, B. Zheng and S. Ge, 2011. Simultaneous optimization of final pit and production schedule in open-pit coal mines. Advanced Materials Research, 323: 222 - 228.

Johnson, T.B, 1969. Optimum open-pit mine production scheduling. International Computr Applicaiton and Operations Research in Mineral Industry, Salt Lake, USA, 539-562.

Kim, Y. C. and W.L. Cai, 1990. Long range mine sequencing with $0-1$ programming. Proceedings of the 22nd International APCOM, Berlin, 11: 131 - 145.

Lamghari, A. and R. Dimitrakopoulos, 2012. A diversified Tabu search approach for the open-pit mine production scheduling problem with metal uncertainty. European Journal of Operational Research, 222(3): 642 - 652.

Marcotte, D. and J. Caron, 2010. Ultimate open pit stochastic optimization. Computers \& Geosciences, 51(2): 238 - 246.

Nasab, H.A., K. Awuah-Offei and H. Eivazy, 2010. Large- scale open pit production scheduling using mixed integer linear programming. International Journal of Mining \& Mineral Engineering, 2(3): 338 - 359.

Pana, M.T. and T.R. Carlson, 1966. A description of a computer technique used in mine planning of the utah mine of Kennecott Copper Corp. Proceedings of the 6lh International Symposium on Computers and operations research in mineral Industries, 332 - 339. The Pennsylvania State University.

Peralta, S., A. P. Sasmito and M. Kumral, 2016. Reliability effect on energy consumption and greenhouse gas emissions of mining hauling fleet towards sustainable mining. Journal of Sustainable Mining, 8: 1 - 10.

Ramazan, S. and R. Dimitrakopoulos, 2013. Production scheduling with uncertain supply: a new solution to the open pit mining problem. Optimization and Engineering, 14(2): 361 - 380.

Shishvan, M.S. and J. Sattarvand, 2015. Long term production planning of open pit mines by ant colony optimization. European Journal of Operational Research, 240(3): 825 - 836.

Xu, X. C., X.W. Gu., Q. Wang, J.P. Liu and J. Wang, 2014. Ultimate pit optimization with ecological cost for open pit metal mines. Transactions of Nonferrous Metals Society of China, 24(5): 1531 - 1537. 